\title{
ARE SMALL AND MEDIUM ENTERPRISES (SMEs) PLANNING FOR STRATEGIC MARKETING IN SOUTH AFRICA?
}

\author{
Louise van SCHEERS*, Khathutshelo Mercy MAKHITHA \\ University of South Africa, Department of Marketing and Retail, South Africa \\ *e-mail: vscheml@unisa.ac.za
}

\begin{abstract}
Substantial evidence shows that strategic marketing planning leads to increased small business performance, yet most small business owners do not draw up a plan for their businesses. This paper presents the results of a secondary research survey on strategic marketing planning of SMEs in South Africa. They indicate that while the higher performing SMEs give a higher priority to marketing than to other business functions, they are still sales- or production-oriented. The higher performing SMEs are more aware of strategic planning tools. They compete with value-added products and good buyer-seller relationships. The findings suggest that broad, small business marketing principles to some extent contribute to the success of SMEs.
\end{abstract}

Keywords: strategic marketing planning, South African SMEs, better performing SMEs, lack of strategic planning know-how.

\section{Introduction}

Strategic planning is a process of envisioning a desired future for the small business, thus making strategic decisions on its mission and objectives as well as on allocating resources to pursue its chosen strategy. Strategic planning therefore involves clearly defining the small business's mission and assessing the current state and competitive landscape. Strategic marketing planning, on the other hand, creates product awareness and interest to ensure an enduring customer engagement. It guides the small business's culture, products and pricing. According to Goldstuck (2010), the total number of SMEs in South Africa is just over 2 million and they contribute between 52 and $57 \%$ to nation's GDP and provide about $61 \%$ to employment, according to Abor and Quartey (2010). It is estimated that they employ $22 \%$ of the adult population in developing countries. SMEs play a vital role in stimulating economic activity, job creation, and poverty alleviation, and their general empowering of living standards has been recognized both internationally and in South Africa (Nieman, Hough and Nieuwenhuizen, 2003). UNIDO (2016) also estimated that SMEs represent over $90 \%$ of private businesses and contribute more than $50 \%$ to employment and gross domestic product (GDP) in most African countries. It is clear that small business is considered important for the South
African economy and thus strategic planning will improve sustainability of these businesses.

Wang, Walker and Redmond (2008) observe that strategic planning is generally more common in better performing SMEs and those who engage in strategic planning are less likely to fail. Moreover, SMEs that engage in strategic planning are also more likely to be those enterprises that are more innovative, that have more newly patented products, that employ new process and management technologies, and that achieve international growth. According to Wang et al. (2008) it is well recognized that strategic planning is rare or nonexistent in a majority of SMEs; however, the reasons for it are not well understood. Yeboah (2012) argues that SMEs face particular strategic decision-making problems. They have limited resources in terms of time, finances and professional expertise, which jeopardise their strategic planning. It seems that they take a more evolving approach to decision-making, which implies that the decision-making process is not structured but rather develop as they go along. According to Tan, Lin, and Eze (2010), most small businesses lack a formal mode of strategic planning. This clearly suggests that the key reason for the failure of SMEs is not only lack of access to finance, but also lack of strategic planning. This is not necessarily due to lack of know-how, but rather a lack of acknowledgement 
of the importance of planning in the ordinary course of business.

Hill (2001) observes that SMEs in Ireland and the United Kingdom do engage in fairly sophisticated strategic marketing planning. The research found some evidence of a nonplanning culture in the operational practices of a few of the firms, particularly in which opportunity-focussed individuals have much influence. All of the respondents in our research did engage in marketing planning with many committed to three-year marketing plans and reviewing the plans annually. Respondents to the research clearly articulated an appreciation of its benefits and value. As a general conclusion, the research contradicts the nature of marketing planning in SMEs as found by previous research, which argued that marketing planning in SMEs is both underutilized and misunderstood. Hills (2001) reflects the status quo, in that small firms are more likely to be populated with graduates with substantial theoretical knowledge of the tools and techniques of formal marketing and that SMEs that do not engage in formal planning are fast becoming a minority. However, in South Africa, it does not seem to be the case; van Scheers (2010) established that a lack of marketing strategic planning skills in South African SMEs has a negative impact on their success and contributes to the high failure rate. Based on this report, it can be argued that South African SMEs do not engage in strategic marketing planning. van Scheers
(2011) also argues that the improvement of marketing skills of small business-owners will solve unemployment problems and rejuvenate a stagnating economy.

According to Wang et al. (2008), it is possible to provide a more fundamental explanation for the apparent lack of strategic marketing planning. The strategic marketing planning of the SMEs may be closely related to owner-managers' personally defined "nonrational" motivations for being in business for which strategic planning is perceived as unnecessary. According to the research, motivational factors can be categorized as either "pull" or "push." Pull factors are associated with owner-managers having a strong positive internal desire go into a small business; "push" factors are linked to similarly strong desires but based on external negative reasons. Overall, financially framed motives are often secondary to more personal and internal drivers as motivations for being in small business. According to the research, ownership motivations and reasons for having a small business are central to understanding the planning practices in SMEs, and these are an alternative explanation to the common focus on barriers to strategic planning to account for the lack or low levels of such planning in many SMEs.

In South Africa, the reasons and statistics for SME business-owners being in business, according to Goldstuck (2010), are indicated in Fig. 1.

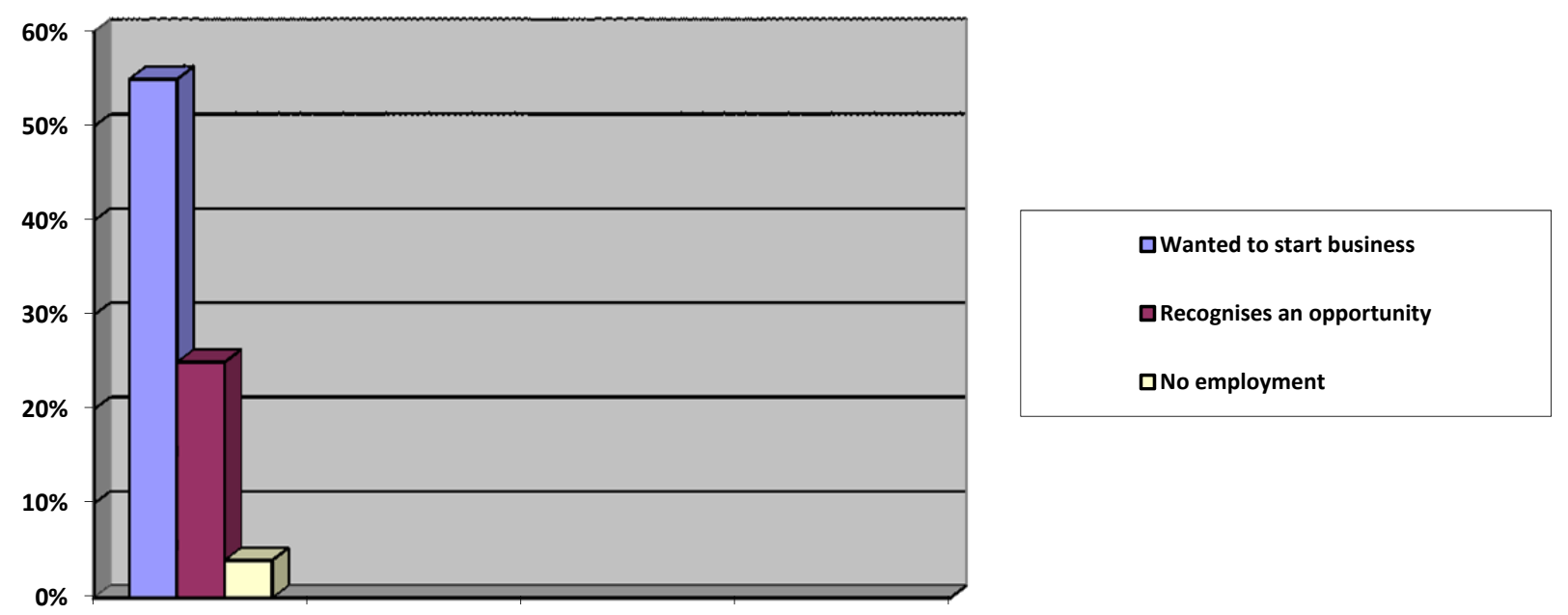

Figure 1. Reasons why SME owners are in business 
From the statistics, above it is clear that $80 \%$ of South African SMEs in the established markets falls into the "pull" category as described by Wang et al. (2008) and therefore it could be argued that these South African SMEs are indeed engaged in strategic marketing planning. If South African SMEs do engage in strategic marketing planning, their understanding of the formal and conventional process of strategic marketing planning and implementation must be investigated to ascertain reasons for their high failure rate. This will be investigated by the current research.

\section{The importance of strategic marketing planning}

Rwigema and Venter (2004) regard the strategic marketing planning phase as critical to success of any business. The strategic marketing management process or system has been designed to help management both precipitate and make strategic decisions, as well as create strategic visions. Abor and Quartey (2010) emphasizes that many strategic blunders occur as a result of not implementing strategic planning in small business.

The strategic marketing planning process is a wellresearched field of marketing management and much literature exists on the subject. The process of developing strategies has been described over the years using various terminology including budgeting, longrange planning, strategic planning, and strategic market management. The different terminologies has similar meanings and are often used interchangeably. However, when they are placed in a historical perspective, some useful distinctions emerge. Strategic planning, the emergence of which is associated with the 1960s, 1970s, and 1980s, is concerned with changing strategic thrusts and capabilities. However, strategic marketing planning focuses on the market environment facing the small business. In Fig. 2, the elements of strategic marketing planning are shown.

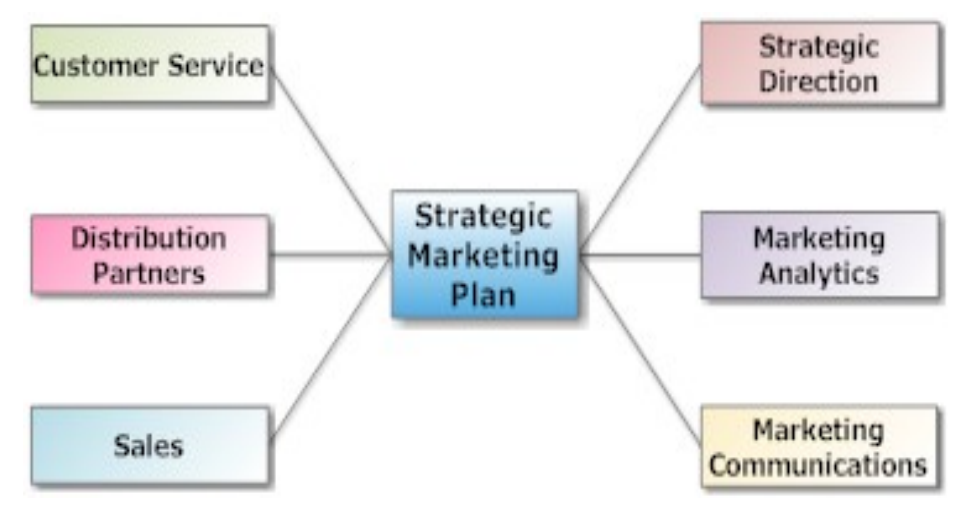

Figure 2. Strategic marketing planning (source: Dludla, 2005)

Van Scheers (2011) points out that there is a lack of availability of marketing experts and specialists within the South African SME sector. Proper strategic planning therefore does not take place, which results in high rates of business failure (Global Entrepreneurship Monitor (GEM, 2012). Lack of marketing and poor strategic marketing planning are the major reasons for SME failures (Hussaina and Wang, 2010). Dludla (2005) indicates that the small businesses still lack the ability to market their products effectively. Van Scheers (2011) revealed that there is a positive relationship between the lack of strategic marketing planning of SMEs and business failure.

According to Wang et al. (2008), SME businessowners' motivations for being in business are central to understanding the strategic planning practices in SMEs and they are used as an alternative explanation to the barriers to strategic planning to account for the lack or low levels of such planning in many SMEs. Goldstuck (2010) recorded that $80 \%$ of SMMEs are in business because they wanted to start a business or recognized an opportunity to start a business. 
If SMEs are engaging in strategic marketing planning processes, it could be argued that their planning seems to be ineffective. The current research will, as a main objective, investigate their understanding of the formal and conventional process of strategic marketing planning and whether the implementation of their planning practices are indeed ineffective or not.

The marketing strategy planning is the process that can allow a small business to concentrate its limited resources on the greatest available opportunities to increase sales and achieve a sustainable competitive advantage. A marketing strategy should be centered on the key concept that customer satisfaction is the main goal. Kroon and Moolman (2007) believe that lack of and poor marketing strategies are the major reasons for the failure of SMEs. Siu (2000) explains that there are established links among strategic marketing practice and eventual performance outcomes of the small business.

Zontanos and Anderson (2004) argue that these practices are limited due to resource constraints in finance, personnel, skills, and attitude toward marketing. It seems to be a no-win situation because strategic marketing planning contributes positively to SME success and the ability to think strategically. Small businesses still face strategic marketing planning challenges, which can and will ultimately determine their future.

\section{$3 \quad$ Strategic planning: the link with marketing}

Small business owners find themselves sometimes so preoccupied with the hard work of running marketing programs, supervising staff, and sales force, and attending to the day-to-day grind that they lose sight of the big picture. However, it is essential to step back now and then to gain perspective, and engage in strategizing. The broad scope of strategic marketing planning includes:

- all the products/services that the company offers,

- all the markets the company serves,

- both environmental and internal variables,
- production, research, finance, and other organizational elements needed for success.

Strategic marketing planning looks beyond the immediate circumstances, in the process clarifying where the small business wants to be in the future. This strategic perspective can be contrasted with the tactical level (which looks at the performance of specific products or markets over a shorter time frame) and operational planning (which focuses on the nitty-gritty of getting the job done). Small businesses that succeed do so by creating and keeping customers. They do this by providing better value for their customers than the competition.

The task of marketing management constantly is to assess which customers they are trying to reach and how they can design products and services that provide better value (create competitive advantage). The main problem with this process is that the environment in which the small businesses operate is constantly changing. So a small business must adapt to these constant changes in the environment and make decisions about how to change the marketing mix in order to succeed. This process of adapting and decision making is known as strategic marketing planning.

\section{Where does marketing planning fit in with the overall strategic planning of a business?}

Strategic planning is encompasses the overall direction of the business. It is concerned with marketing and also involves decision-making about production and operations, finance, human resource management, and other business issues. The objective of a strategic plan is to set the direction of a business and create a strategy so that the products and services it provides meet the overall business objectives.

In Fig. 3, strategic management models indicate the complete strategic management and marketing process, which begins with customer needs identification, evaluating the different environments with SWOT analysis to make strategic choices, and create effective strategic marketing plans. 


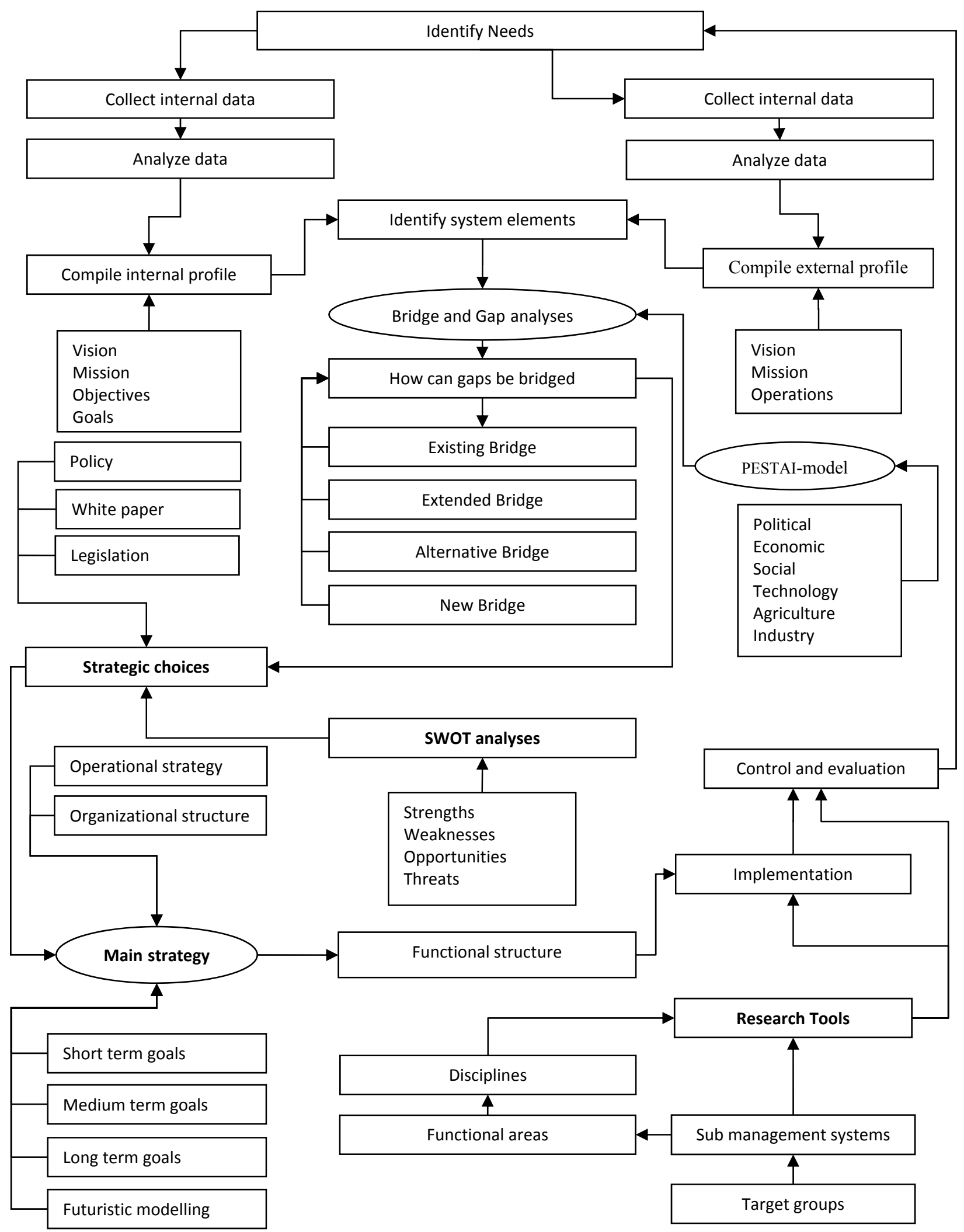

Figure 3. Strategic management model

(source: www.themarketingprocessco.com. 2015) 
As indicated in Fig. 3, strategic marketing planning forms part of the functional areas. Marketing has a key role to play in strategic planning, because it is the task of marketing management to understand and manage the links between the business and the environment. For example, in many small businesses, there is only one geographical market and a limited number of products (perhaps only one product!). However, consider the challenge faced by marketing management in a multinational business, with hundreds of business units located around the globe, producing a wide range of products. How can management keep control of marketing decision-making in such a complex situation? Managers therefore rely on a well-organized marketing planning process.

\section{Develop a marketing strategy for SMEs}

The benefits of a well-planned marketing strategic planning are numerous. Small business owners often rely solely on their intuition to make business decisions. While this informal knowledge is important in the decision-making process, it may not provide you with all the facts you need to achieve marketing results. A marketing planning strategy will help in defining business goals and develop activities to achieve them:

1) Describe your company's unique selling proposition (USP);

2) Define your target market;

3) Write down the benefits of your products or services;

4) Describe how you will position your products or services;

5) Define your marketing methods. Will you advertise, use Internet marketing, direct marketing, or public relations?

Marketing participants often employ strategic models and tools to analyze marketing decisions. When beginning a strategic analysis, the 3Cs (corporation, customer, competitors) can be employed to get a broad understanding of the strategic environment. An Ansoff matrix is also often used to convey an organization's strategic positioning of their marketing mix. The 4Ps (product, price, promotion and place) can then be combined to form a marketing plan to pursue a defined strategy.

\section{Discussion}

Secondary research indicates that strategic marketing planning is the backbone for small business success. While traditionally strategic marketing was associated with large businesses, small businesses also need to employ strategic marketing planning in order to survive (Blankson and Stokes, 2002; Hill, 2001; Siu, 2000; Siu, et al., 2004). However, marketing strategic planning in the small business is different from marketing in the larger organization. Due to the intensity of competition, changing market and customer requirements, small businesses need to adapt their marketing activities to reflect these changes. Small businesses are competing in an environment that is global in nature and scope, information rich and knowledge based, which continue to influence how they operate (Abimbola and Vallester, 2007). Strategic marketing planning is the process of analyzing environmental, competitive, and business factors and forecasting future trends in business areas, set objectives and formulating strategies, selecting target market in each business units, establishing marketing objectives and development, implementing and managing marketing program positioning strategies - in effect, a marketing plan. Strategic marketing planning determines how the small business is going to compete against its major competitors. Venter and Van Rensburg (2009) points out that it involves determining the competitive advantages that may arise as a result of the ability of the small business to perform better than its competitors in some areas. Walker, Boyd and Larreche (2016) correctly indicate that the success or failure of a marketing strategy depends on whether the strategy fits the realities of the small business's external environment. It seems that it is therefore important for SME owners to monitor and analyze opportunities and threats posed by factors outside the small business before they could formulate a marketing strategy.

Secondary research indicates that the success or failure of a marketing strategy depends on whether the strategy fits the realities of the small business's ex- 
ternal environment. However, as Stokes (2006) points out, SMEs are generally known to have informal marketing plans, which are short term in nature and involve informal, unplanned activity that relies on the intuition and energy of the ownermanager. Secondary research also indicates that the practice of strategic marketing planning can be limited due to resource constraints in finance, personnel, skills, and attitude toward marketing. It does not seem that they conduct situation analyses nor have any knowledge of strategic marketing planning tools.

Thomas (2013) studied the strategic marketing practices of SMEs with specific focus on practices such as establishing marketing objectives, identifying market segments, marketing to specific target markets, engaging in product packaging activities with other industry sectors, and working to a written marketing plan. He indicates that SMEs fail to utilize strategic marketing practices comprehensively. Strategic marketing practices such as knowledge of current market conditions and consumer tastes were positively related to SME performance (Julien and Ramangalahy, 2003; Berthon, et al., 2008). Simpson (et al., 2006) examines drivers of marketing effort such as the presence of a marketing department and marketing representation at the board level. SMEs do not monitor and record the performance of competitors' performance.

It seems that the higher performing SMEs tend to adopt a longer-term approach to planning and to use strategic or annual marketing planning. This research concludes that higher performing SMEs tend to use strategic marketing planning more frequently and pay more attention to comprehensive situation analysis than their lower performing counterparts. The findings suggest that broad, small business marketing principles, to some extent, contribute to the success of SMEs.

\section{$7 \quad$ Bibliography}

[1] Abor, J. Quartey, P., 2010. Issues in SME development in Ghana and South Africa. International Research Journal of Finance and Economics. Issue 39 available at http://www.eurojournals. com/irjfe_39_15.pdf.
[2] Abimbola, T., Vallaster, C., 2007. Brand, organisational identity and reputation in SMEs: an overview. Qualitative Market Research: An International Journal, Vol. 10, Iss. 4, pp. 341-348.

[3] Blankson, C., Stokes, D., 2002. Marketing practices in the UK small business sector. Marketing Intelligence \& Planning, 20(1), pp.49-61.

[4] Dludla, N.J., 2005. Marketing management strategies in roadside craft markets in Umkhanyakude Municipal area, Kwazulu-Natal. Unpublished masters dissertation, University of Kwazulu-Natal, Pietermaritzburg.

[5] Gem, 2012. www.gem.org.za.

[6] Goldstuck, A., 2012. Internet matters: the quiet engine of the South African economy. [online] Available from: http://hsf.org.za/resourcecentre/focus/focus-66/AGoldstuck.pdf.

[7] Hussaina, I., Si, S. and Wang, L., 2010. Comparative study on internal and external CFFs on SMEs. Journal of Small business and Entrepreneurship, Vol. 23, Issue 4.

[8] Hill, J., 2001. A multidimensional study of the key determinants of effective SME marketing: Part 1. International Journal of Entrepreneurship Behaviour \& Research, 7(5), pp.171-204.

[9] Lamb, C., W, Hair, J.F., McDaniel, C., Boshoff, C., Terblanche, N., Elliot, R. and Klopper, H.B., 2011. Marketing (4th ed.). Cape Town: Oxford University Press.

[10] Julien, P.A., Ramangalahy, C., 2003. Competitive strategy and performance of exporting SMEs: An Empirical Investigation of the impact of their export information competencies. ET \& $\mathrm{P}$, Spring.

[11] Kroon, J., Moolman, P.L., (2007). Entrepreneurship. Pretoria: Kagiso Publishers.

[12] Makhitha, K.M., 2013. Buyer behaviour of craft retailers in South Africa. Pretoria: University of Pretoria. [Unpublished PhD in Marketing Management - thesis].

[13] Makhitha, K.M., 2016. Marketing strategies of small craft producers in South Africa: practices and challenges. The Journal of Applied Business Research, May/June 2016, Vol. 32, No. 3, pp.118. 
[14] Nieman, G., Hough, J. and Nieuwenhuizen, C., 2003. Entrepreneurship: a South Africa perspective. Pretoria: Van Schaik.

[15] Rwigema, H., Venter, R., 2004. Advanced Entrepreneurship. Cape Town: Oxford University Press Southern Africa.

[16] Shacklenton, C.M., Shackleton, S.E., Buiten, E. and Bird, N., 2007. The importance of dry woodlands and forests in rural livelihood and poverty alleviation in South Africa. Forest Policy and Economics, Vol. 9, pp.558-577.

[17] Siu, W., 2000. Marketing and company performance of Chinese small firms in Hong Kong. Marketing intelligence \& planning, 18(5), pp.292-307.

[18] Siu, W., Fang, W., and Lin, T., (2004). Strategic marketing practices and the performable of small and medium-sized enterprises (SMEs) in Taiwan. Entrepreneurship \& Regional Development: An International Journal, 16(2), pp.61178.

[19] Tan, K.S., Siong Choy Chong, Binshan Lin, Uchenna Cyril Eze, (2010). Internet-based ICT adoption among SMEs: Demographic versus benefits, barriers, and adoption intention. Journal of Enterprise Information Management, Vol. 23, Iss. 1, pp.27-55.

[20] Tang, Y., Wang, P. \& Zhang, Y., 2007. Marketing and business performance of construction
SMEs in China. Journal of Business \& Industrial Marketing. 22(2), pp.118-125.

[21] Venter, P., Jansen van Rensburg, eds., M., de Viliers, J.C., Drotskie, A., Ehlres, L., 2009. Strategic Marketing: Theory \& Applications for Competitive Advantage. Oxford University Press, Southern Africa.

[22] UNICO, 2016. https://www.unido.org/fileadmin/ user_media_upgrade/Resources/Publications/EB OOK.

[23] Van Scheers, L., 2011. SMEs' marketing skills challenges in South Africa. African Journal of Business Management, Vol. 5(13), pp.50485056, DOI: 10.5897/AJBM10.007.

[24] Wang, W., Walker, E., Redmond, Janice., and Breen, J., 2008. Making plans - Home-based businesses. Available at: http://works.bepress. $\mathrm{com} / \mathrm{janice}$ _redmond $/ 33 /$.

[25] Yeboah, K., 2012 as in Busetta, A., Cetorelli, V., Stranges, M., 2016. Remittance behaviours of foreigners in Italy. International Migration, 2016, Vol. 54(2), pp.98-118, DOI: 10.1111/imig. 12213 .

[26] Zontanos, G., Anderson, A.R., 2004. Relationships, marketing and small business: an exploration of links in theory and practice. Qualitative Market Research: An International Journal, Vol. 7(3), pp.228-236.

[27] www.themarketingprocessco.com, 2015. 